\title{
China's Military Increase: A Security Dilemma In Asia Pacific
}

\author{
Mufidah Fariani \\ Universitas Islam Negeri Syarif Hidayatullah Jakarta \\ Badrus Sholeh \\ Universitas Islam Negeri Syarif Hidayatullah Jakarta \\ Email: mufidahfariani@gmail.com
}

\begin{abstract}
This research seeks to show how theories and concepts can explain the rise in China's military and its impact on the Asia Pacific. Through the lens of theory and concept, this paper will also show what causes China to increase its military and why this is a security dilemma for the Asia Pacific. This paper uses the theory of Offense and Defense and also the concept of Security Dilemma. Offense and Defense Theory is intended to explain how the balance between offense and defense in the Asia Pacific region occurs so that it does not cause significant conflict in the Asia Pacific Region. The Security Dilemma concept is used to analyze the impact of China's rising military making the Asia Pacific countries a security dilemma. By using these theories and concepts, it is produced that if Defense is more dominant than Offense, then war will be avoided here, which plays the role of Offense, namely China and Asia Pacific countries play Defense. But China's behavior also cannot be separated from its country's history and position. So, China and the Asia Pacific region have contributed to the offense-defense balance and security dynamics in the Asia Pacific region.
\end{abstract}

Keywords: China, military, Security dilemma, Asia Pacific, offense, defense

\begin{abstract}
Abstrak
Melalui kacamata teori dan konsep, tulisan ini akan menunjukkan apa yang menyebabkan China meningkatkan militernya dan mengapa ini menjadi sebuah dilema keamanan bagi Asia Pasifik. Tulisan ini menggunakan teori Offense dan Defense dan juga konsep Security Dilemma. Teori Offense dan Defense dimaksudkan untuk menjelaskan bagaimana keseimbangan antara offense dan defense di kawasan Asia Pasifik ini terjadi sehingga tidak menimbulkan konflik yang berarti di Kawasan Asia Pasifik. Adapun konsep Security Dilemma digunakan untuk menganalisis dampak dari meningkatnya militer China membuat negara-negara Asia Pasifik menjadi dilema dalam hal keamanan. Dengan menggunakan Teori dan Konsep tersebut maka dihasilkan bahwa jika Defense lebih dominan daripada Offense maka perang akan terhindari disini yang berperan sebagai Offense adalah China dan negaranegara Asia Pasifik berperan sebagai Defense. Namun perilaku China juga tidak lepas dari sejarah dan posisi negaranya. Jadi, China dan Asia Pasifik turut berkontribusi atas keseimbangan offense-defense dan dinamika keamanan di kawasan Asia Pasifik.
\end{abstract}

Kata kunci: China, militer, security dilemma, Asia Pasifik, offense, defense

\section{Introduction}

International political relations are undergoing a transformation in influencing other countries or regions. This condition shows that the domination of conventional international security issues has not been completely destroyed. This means that international politics still regards military 
power as an indicator in maintaining the position of domestic, regional and global stability. Military power is still dominant in international politics, marked by the intense intensity of countries in the world in increasing their military spending (Fathun, 2016).

Since the end of the Cold War, scholars and policymakers have widely regarded the Asia Pacific as a "ripe for rivalry" and risked increasing military competition (Friedberg, 1993). Its development in the last decade has agreed to this expectation. This change inability is the main cause of China's rise, and economic growth throughout the region, military surging spending, and military modernization seem to have created a more volatile climate and the potentially vicious cycle of weapons and armament. Simultaneously, this step and scale of change creates uncertainty about the future, which in turn will exacerbate existing insecurities. In reflecting on this regional trend, many observers are suggesting that an arms race is taking place in the Asia Pacific, and several other countries show a security dilemma as the driving force of this competition (Liff \& John Ikenberry, 2014).

After the cold war, the international order also changed especially related to issues that were high politics. The issue of high politics seems to no longer be the main focus of countries in the world, especially concerning the issue of military power. The countries prefer a peaceful, safe and prosperous life. So the countries also begin to build an issue that is low politics in which aspects such as the economic, social, and cultural tendency to be the main focus of countries in building a relationship between countries (Akbar, 2012).

However, along with technological advances and the rapid development of globalization, encouraging the transformation of values carried out by political actors which then reappear high politics issues along with low politics issues. Technological developments encourage the emergence of new transformations in the field of high politics, especially in terms of military power with new operational concepts. Technological developments not only produce new war instruments but also require academics and military practitioners to think of new advantages and threats raised by these innovations.

The superiority of military technology often determines the fate of a nation when dealing with the military strength of other countries (Roza, 2012). So that each country is required to increase the superiority of its military technology 
continuously, and if possible to hamper the development of military technology in other countries that can threaten the national security interests of a country. In the current era of globalization, countries in the world are preoccupied with maximizing their military strength by increasing the military budget of their respective countries. Then this is what causes the security dilemma (Satris, 2015).

The emergence of this security dilemma is very influential in countries in the world, especially on the issue of high politics, namely military power to continue to increase its power both in defense and security by eliminating or avoiding the domination of threats from other countries. We can see China from year to year its military budget continues to experience a significant increase (Satris, 2015).

China's increasing military budget is driven by concerns over potential threats from Asia Pacific countries such as Japan and others. This is what lies behind China continuing to strengthen its military power. The impact of this has led to various security dilemmas in the Asia Pacific region, especially Japan.

\section{Theory and Concept}

In this journal, the author will use the Offense-Defense theory formulated by Stephen Van Evera (van Evera, 1998). This theory also relates to Robert Jervis's concept of the security dilemma. In accordance with the title, this journal will also use the concept of a security dilemma. The security dilemma is defined as an action and reaction between several countries, where one of the countries makes an increase in security, but the increase is considered to weaken the security of other countries (Jervis, 1985). The basic assumption of offense-defense balance is, if the offense of a country in an area increases, the security dilemma will increase, then followed by an arms race and war can occur, so war can be prevented if the defense can dominate rather than offense. Referring to this matter, the author will position China as an offense in the Asia Pacific region. But in this journal, the author will not explain why the war did not take place in the region, the author only tries to explain how the security dilemma of the Asia Pacific countries responds to China's rising military issues.

The author uses this offensedefense theory because I feel this theory is considered capable of explaining China's behavior in improving its military. Then this theory can also include phenomena that are considered important as the cause of war (van Evera, 1998). And also offense-defense theory can be applied in the real world. Maybe Offense that 
dominates is hard to find now. But the view of threats is still widespread throughout the world. One of them is the threat from Chinese military power, which will be discussed in this paper.

This theory offers a new perspective in international politics based on the argument that war can be prevented when the defense gains an advantage over the offense-defense balance scheme. Van Evera argued that war would occur if conquest was easy to do, and there was a shift in the balance of offense that could increase the risk of war. Evera also explained that there are at least ten causes of war if offense dominates the balance in a region (van Evera, 1998).

1. If countries are easy to control, this situation will open up opportunities for expansion, even for middlestrength countries.

2. Self-defense is difficult, so the country becomes increasingly insecure. This situation encourages them to strengthen themselves in a defensive way;

3. The sense of insecurity of the country also encourages them to reject the expansion of other countries in more violent ways. Increasing power by other countries can threaten the national security of one's own country, so it is not impossible that expansionism can give birth to a tougher response.

4. Opportunities for the state as the first attacker are open, increasing the risk of preemptive war.

5. A greater window of opportunity and vulnerability increases the danger of preventive warfare.

6. Countries more often adopt diplomatic tactics fait accompli, and tactics like more often trigger a war.

7. Countries are not cooperative, so negotiations often fail and disputes are difficult to end.

8. Countries put foreign and defense policies in strict secrecy, increasing the risk of miscalculation and diplomatic blunders.

9. Armaments races occur so fast that they are harder to control, increasing the risk of preventive warfare and false optimism warfare.

10. Offense dominance is self-feeding, if conquest is easier, then the state will adopt policies that make it easier (for example, more offensive military policies) to carry out conquests.

This research uses a descriptive qualitative approach, this research is a process of research and understanding based on social phenomena in the international community today. This research is also descriptive because it can 
be used to observe facts that occur in the international world, assisted with theories in analyzing these phenomena, by combining views, theories, and ideas to analyze a phenomenon, a conclusion will be in the form of new knowledge (Creswell, 2013). The problem or phenomenon examined in this study is the phenomenon of the Chinese military increasing from year to year and used as a security dilemma by the Asia Pacific countries.

This research will use secondary data sources. Research that uses secondary data sources is research originating from library sources, such as books, journals, research results, and data from internet sites. The author uses these secondary data sources to facilitate the authors in analyzing the research studied. The secondary data sources used in this study are library research, such as books, research results, and journals. The places used in library research are the central library of UIN Syarif Hidayatullah Jakarta and the FISIP Library of UIN Syarif Hidayatullah Jakarta. Then this research also uses internet facilities in the process of collecting data related to the research problem.

\section{Literatur Review}

In raising the title of this journal, the author seeks to conduct a review of research deemed relevant to the title of this journal, namely the Enhancement of the Chinese Military and its impact on the Asia Pacific region. Previous studies will be a benchmark and foundation for writers in developing the scope of research. The following are some of the previous studies that the authors used as a reference for conducting research comparisons. The first is a journal written by Fadhil Alghifari and King Nathania Olga Letticia the title is "Analysis of the Offense-Defense Theory of Japanese Defense Policy Reform in Security Dynamics in East Asia". In this journal explained that one of the determinants that influence the country in behaving offense or defense is military factors. The unpredictable dynamics of East Asian security have put Japan under pressure both from the United States and also domestically to direct this defense focus and expand its military operations, in order to respond to threats coming from China and North Korea (Alghifari \& Olga Letticia, 2016). Japan, from a different perspective, also has a strong incentive to reduce its dependence on the United States. As a country that is worried about the rising power of China, Japan feels that America will not always take care of 
security problems there. Maintaining a strong military with offensive capabilities can make Japan feel safer. This does not mean that Japan will become an aggressive country like World War II. It's just, as Mearsheimer said, "Japan wants to be a normal country, with strong military capabilities, flexible for self-defense". The difference of this journal with "Analysis of Offense-Defense Theory Against Japanese Defense Policy Reform in the Dynamics of Security in East Asia" is that the journal discusses the state of Japan that is doing defense while this research explains about China which in this study is in the Offense position. But the similarity lies in the theory of this study and a journal entitled "Analysis of the Offense-Defense Theory Against Japanese Defense Policy Reform in the Dynamics of Security in East Asia" both use the offensive-defensive theory which is the theory can explain the phenomena that the authors discuss in this journal.

Next is a journal written by Angga Nurdin Rachmat entitled "Security Dynamics of the Asia Pacific Region in the Competition of Chinese and United States Maritime Power" which in this journal explains the dominance of the United States that has long existed in the Asia Pacific region but now the United States has rivals in its dominance in the
Asia Pacific is China. China has begun to develop economically, politically, and also security. However, the difference between that Journal and this research is that in the journal the focus is on two countries, namely the United States and China about their competition in maritime power in the Asia Pacific region, including the South China Sea conflict mentioned in the journal that it is a stage of rivalry between China and the United States. While this research does not discuss the competitiveness of Chinese maritime power, in this study the author focuses more on increasing military power from China and its impact on countries in the Asia Pacific.

\section{The factors of China's military budget increasing}

Based on the official defense document of China China White Paper on National Defense 2008, it was stated that the basic principle of increasing the defense and military budget of the Chinese armed forces, is based on the same continuity between defense needs and economic development growth (Information Office of the State Council of the People's Republic of China, 2009). The increase in the defense and military budget is adjusted to the needs of the Chinese armed forces in the future by 
prioritizing defense modernization within the armed forces that have high efficiency and low funding.

In the approximately 30 years since China opened up to the market in 1979, China has sought to build a strong internal army force that is in harmony with China's economic growth and development. For this reason, the increase in the defense and military budget of the Chinese armed forces is always maintained at a reasonable level and adjusted to the level of China's economic growth. From 1978 to 1987, China focused on economic development, provided a small portion of the budget in the defense and security sector. During that time period, the average increase in China's defense budget was 3.5 percent of China's domestic GDP which was 14.1 percent per year far from the country's financial expenditure which amounted to around 10.4 per year (Information Office of the State Council of the People's Republic of China, 2009).

Increasing the military budget of a country, including China, can be influenced by security factors both internationally and regionally. The influence of external conditions, in this case, the stability of regional security is strongly influenced by the countries that are within the region. The problem of security stability in the East Asian region in the shadow of conflict is very vulnerable. These conflicts are territorial disputes, past conflicts and some forms of conflict that are categorized as inter-state or intra-state. The most serious form of threat from the Chinese perspective is the defense alliance that Japan has built with the United States. The building of an alliance between Japan and the United States began in 1951 which aimed to stem the anti-Soviet movement in the Asia Pacific region during the Cold War. The alliance after the end of the cold war is still running intensively.

\section{Japan}

Almost every year, China increases its weapons budget, this means that each year China's military strength continues to increase from year to year. With the fact that the rise of the Chinese military has led to various negative perceptions, especially from countries in the Asia Pacific region such as Japan. For other Asia Pacific countries, assess that there is a tendency of China to become a superpower country in the Asia Pacific. Military factors become one of the determinants that influence a country in offense or defense actions. The security dynamics that occurred in this Pacific region made Japan depressed especially with the rise of China's military. From comparative data on military budgets 
in East Asia, we can know that in that region Japan has a small number of manpower and military budgets, far below China (Cordesman \& Hammond, 2011). Actually, if Japan does offensive strength, Japan will feel safer. This action does not mean Japan is aggressive like during World War II but Japan only wants to have strong military capabilities and can be used to defend the country.

The increase in China's military indicates that there is a security dilemma from regional countries, as well as to maintain China's hegemony as a country declared as a superpower country in the Asia Pacific region. The security dilemma has a worrying effect on countries in the world. The assumption that is built in the security dilemma is that the world is in an anarchic position. Japan initially emerged as one of the countries that had the potential to become rulers in the Asia Pacific, and this became one of its own fears for China. This is because Japan, which is the main power of East Asia, appeared in history. China does not want to see Japan become a major power in the East Asian region or the Pacific. China also does not want to see Japan has strong military power. For China, Japan must remain in a subordinate position and China will continue to hold back all kinds of Japanese movements to become a major force in the East Asia and Pacific region (Mulgan, 2005).

According to China, Japan is a country that has a large potential for conflict with the country. Besides caused by historical factors, also influenced by the closeness between Japan and the United States in terms of building a defense system. Because China sees that Japan has experienced a shift in military policy, from initially leaning towards local defense and now heading towards the region and from a form of passive defense began to shift towards active defense. In other words, the two countries are equally dilemma in interpreting the actions of other countries, whether the other country aims to threaten or not, and also a dilemma in interpreting the capabilities of other countries. Japan, which is one of the countries in the Pacific which experienced a security dilemma over the rise of the Japanese military, is now trying to compensate and also begin to increase its military strength.

China identified that the shift occurred in several ways. First, there was a geo-strategic shift in Japan from the north (Russia and Korea) to the West (China) and South (ASEAN). Second, the danger of Japan's nuclear capabilities. Third, the redefinition of security cooperation between Japan and the United States and the revision of the Japanese defense policy 
guidelines, and fourth is the defense cooperation of Japan and the United States of America has a common goal to inhibit the pace of China in the East Asian Region because China is a common threat to the two countries. Because in order to strengthen the alliance it is possible for the United States to use Japan to limit the pace of Chinese growth in the East Asian Region (Kamindang, 2007).

What Robert Jervis said described that if a country increases its ability to defend itself, then that increase can be too much and too little. Too much because that ability can also be used to attack other countries, too little because other countries that feel threatened will also increase their capabilities and will make the first country insecure (Jervis, 1985). This actionreaction model will occur in improving the quality and quantity of weapons and mobility or transfer of weapons to strategic areas or to areas that can reach other countries (Buzan \& Hansen, 2009).

Van Evera's offense-defense theory, in my opinion, is clear in explaining the defense policy pursued by Japan. This theory also shows that Japan has a role as a defender by increasing its military capabilities because it is driven by Chinese offense. Japan's geographical conditions adjacent to China made Japan have to increase its military because of threats from China. So Japan also contributed to the balance of offensedefense and security dynamics. Perhaps the benchmark is that war has not occurred to this day in the region. This proves the assumption of offense-defense theory, namely, war can be avoided if defense dominates or balances offense dominance. But this theory still cannot explain the extent to which offense-defense balance can be measured.

\section{Indonesia}

The end of the cold war marked the beginning of the development of more mature international cooperation. The absence of blocs that previously limited countries to interact with each other then became a moment of freedom. At this stage, the state can very freely implement national interests without the intervention and influence of the alliance bloc. So that cooperation is no longer built on the basis of group solidarity but with consideration of mutualism or mutually beneficial relationships. On the other hand, the situation then raises uncertainty in international politics - especially in the security dimension - where a country cannot guess the movements of opponents or friends. This phenomenon was later identified by experts as a 'security dilemma'. The theory states that the 
potential for security competition arises when a country feels threatened when its competitor's defense index is at a level higher than its national security capacity. This situation can lead to arms races due to a lack of mutual confidence (Confidence Building Measure) between countries (Jervis, 1985). International cooperation, in this case, can be a solution to prevent security instability.

Indonesia and China have a dynamic relationship in the long history of relations between the two countries. China's contribution has more or less facilitated Indonesia's political steps in the international world in the early days of independence. This good relationship had experienced tension when the Indonesian government formally suspended relations in reaction to China's involvement in the Indonesian Communist Party's rebellion movement. However, with various considerations, the reconstruction of the two partnerships can be achieved

Furthermore, the crisis of Indonesia-China relations resurfaced during the reign of Joko Widodo, where there were incidents of sinking Chinese trawlers sailing - and fishing - around the Natuna Island. For this action, the protest note issued by the Chinese government. But this was ignored by Indonesia who felt that the step was appropriate because, in addition to the article on Natural Resource theft, the Chinese had also violated the country's sovereignty by entering territorial territory without permission. (Rohingati, 2014).

The occurrence made the government aware of the potential threat of the struggle for territorial sovereignty by China which at the same time was also showing its aggressive attitude in the South China Sea. But the tension can be mitigated by various diplomatic efforts. The ups and downs of relations between the two countries must be responded to and dealt with by forming more intensive cooperation. There are several alternative forms of cooperation that Indonesia can develop with China, especially in responding to the security dilemma caused by the South China Sea conflict.

One of the strategic partnership frameworks between Indonesia and China is increased cooperation in the defense sector. The main objective of this collaboration is to increase the trust of the two countries and build a common perception of global and regional security issues (Rachmayanti, 2013)

Alexander Wendt said that regional security can be deliberately constructed socially through social interaction. Furthermore, these interactions will form a common identity and interests. This 
condition can be realized if it meets three main foundations, namely the division of knowledge, division of material resources and practicality (Wendt, 1995). This is then reflected in the activities carried by the two countries in the dimension of defense relations.

In undergoing cooperation in the field of defense with China, Indonesia wherever possible directs the interaction in a cooperative-cooperative pattern. This is based on Indonesia's need to increase military capacity and capability to strengthen national defense. In the future, Indonesia and China as developing and emerging countries in the region are expected to be able to contribute to maintaining security and peace in the international environment, especially in the regions. Security instability due to disputes in the South China Sea should be resolved through the intensity of cooperation in the defense sector between the two countries

\section{Conclusion}

The emergence of China in the context of global politics is mainly related to the increase in its military and security which continues to increase, becoming a special spotlight by countries in the world in general and in particular in the Asia Pacific region. Asia Pacific countries that were born from the assumption of concerns about China's military increase, making the Asia Pacific improve its defense and security systems as a focus in creating a strong state order. The security dilemma experienced by countries in the Asia Pacific region requires to take one step ahead of countries that are considered as rivals as well as threats. This security dilemma is a condition when the state is confronted with security problems in which there are two or more difficult choices in interpreting the military policies of other countries, whether the policies of other countries are aimed only at defense or attack. This is what was done by the Asia Pacific countries to anticipate from all the possibilities that will happen. Thus, the Asia Pacific countries feel the need to continue to improve the military defense system in order to maintain the country's sovereignty.

Based on the explanation above, the writer concludes that the development and improvement of the military cannot be separated from the past security dilemma. This is based on a number of countries that have had conflicts with China both in world wars and in contemporary wars, also doing the same thing. Although it can be seen that the Chinese economy is slowing down in growth, this is not a reason for China to modernize its military forces. 
Military spending that always goes up every year shows China's consistency in maintaining security. With neighboring geopolitical conditions with countries such as Japan and South Korea which have long been enemies of China, it shows that China will not bring mistakes in the past as a repeat. This is in accordance with the work ethic of Chinese people who do not want to underestimate local to international conditions.

For this reason, this paper can conclude that China and the Asia Pacific contribute to the balance of offensedefense and security dynamics in the Asia Pacific region. In addition, the authors also see that Japan ultimately played a role in maintaining the status quo in East Asia where war did not occur until now in the region. This proves the assumption of offense-defense theory, namely, war can be avoided if defense dominates or balances offense dominance.

However, this theory is still unable to explain the extent to which the offensedefense balance can be measured in detail. In addition, the explanation of this theory is only limited to situations that have characteristics in accordance with the assumptions given. In general, offensedefense theory can offer a broad view of the causes of war and the dynamics of security and defense in a particular area which can be proven by the analysis raised in this paper. So, it can be concluded that this theory is still relevant in seeing the causes of war and state behavior in the dynamics of international relations in the contemporary era at this time.

\section{References}

\section{Books}

Buzan, B., \& Hansen, L. (2009). The evolution of international security studies. In The Evolution of International Security Studies. https://doi.org/10.1017/CBO9780511 817762

Creswell, J. (2013). Qualitative, quantitative, and mixed methods approaches. In Research design.

Jervis, R. (1985). From Balance to Concert: A Study of International Security Cooperation. World Politics. https://doi.org/10.2307/2010351

\section{Journals and Online Jurnals}

Akbar, D. (2012). Regionalisme dalam Studi Hubungan Internasional. Indonesian Journal of International Law.

Alghifari, F., \& Olga Letticia, R. N. (2016). Analisis Teori OffenseDefense Pada Reformasi Kebijakan Pertahanan Jepang Dalam Dinamika Keamanan Di Asia Timur. Global: Jurnal Politik Internasional. 
https://doi.org/10.7454/global.v18i1.4 5

Fathun, L. M. (2016). Pengaruh Peningkatan Kekuatan Militer Tiongkok Terhadap Keamanan Stabilitas Regional Asia Timur. The Politics.

Friedberg, A. L. (1993). Ripe for Rivalry: Prospects for Peace in a Multipolar Asia. International Security. https://doi.org/10.2307/2539204

Liff, A. P., \& John Ikenberry, G. (2014). Racing toward tragedy? China's rise, military competition in the Asia Pacific, and the security dilemma. International Security. https://doi.org/10.1162/ISEC_a_0017 6

Rohingati, S. (2014). Penenggelaman Kapal Ikan Asing: Upaya Penegakan Hukum Laut Indonesia. Dpr, VI(24). Retrieved from http://berkas.dpr.go.id/puslit/files/info _singkat/Info Singkat-VI-24-II-P3DIDesember-2014-28.pdf

Roza, R. (2012). Dual-Use Technology Jepang dan Kepentingan Keamanan Nasional Amerika Serikat. Jurnal Hubungan Internasional. https://doi.org/10.18196/hi.2012.0012 $.107-122$

Satris, R. (2015). Peningkatan Anggaran Persenjataan Militer China sebagai
Bagian dari Security Dilemma di Kawasan Asia Pasifik. The POLITICS: Jurnal Magister Ilmu Politik Universitas Hasanuddin.

van Evera, S. (1998). Offense, Defense, and the Causes of War. International Security.

https://doi.org/10.2307/2539239

Wendt, A. (1995). Constructing International Politics. International Security.

https://doi.org/10.2307/2539217

Official Publications, Reports, and Online Sources

Cordesman, A. H., \& Hammond, R. (2011). The Military Balance in Asia: 1990-2011 A Quantitative Analysis. In Center for Strategic and International Studies. Retrieved from https://csis-

prod.s3.amazonaws.com/s3fspublic/legacy_files/files/publication/1 00914_AsiaMilitaryBalance2010.pdf

Information Office of the State Council of the People's Republic of China. (2009). China's National Defense in 2008. Defense.

Kamindang, E. L. (2007). Tantangan China Sebagai Superpower Di Asia Timur. Program Pascasarjana Universitas Gadjah Mada. 
MANDALA:

Vol.3 No.2

Jurnal Ilmu Hubungan Internasional

Mulgan, A. G. (2005). Why Japan still

Pemerintahan Presiden Susilo matters. Asia-Pacific Review.

Bambang Yudhoyono (2004-2013).

https://doi.org/10.1080/13439000500

Hubungan Internasional.

394162

Rachmayanti, N. (2013). Dinamika

Hubungan Bilateral Indonesia-

China(Tiongkok) Pada Era 